\title{
Physicochemical Analysis of Dashanga Agada - An Ayurvedic Formulation
}

\author{
Dr. Nitin B. Patil ${ }^{1}$ Dr. S.K. Hiremath ${ }^{2}$ Dr. Nagasri N. Ekbote ${ }^{3}$ \\ Mr. Ajit Lingayat ${ }^{4}$ \\ ${ }^{I} P G$ Scholar, Dept. of Agada Tantra, KLEU's, Shri. BMK Ayurved Mahavidyalaya and \\ Research Centre, Belgaum, Karnataka \\ ${ }^{2}$ Professor and HOD, Dept. of Agada Tantra, KLEU's, Shri. BMK Ayurved Mahavidyalaya and \\ Research Centre, Belgaum, Karnataka \\ ${ }^{3} P G$ Scholar, Dept. of Panchakarma, KLEU's, Shri. BMK Ayurved Mahavidyalaya and \\ Research Centre, Belgaum, Karnataka \\ ${ }^{4}$ Technical expert, Pharmacognosy, Central Research Facility, KLEU's Shri BMK Ayurved Mahavidyalaya and \\ research centre, Belgaum, Karnataka
}

\begin{abstract}
:
Background: Standardization of herbal formulation is essential to assess the quality of drugs. This article reports on standardization of Dashanga Agada, an Ayurvedic formulation indicated in various poisonous and non-poisonous conditions by Ayurvedic as well as traditional Keralian Visha Vaidyas.

Aims: Physicochemical standardization of Dashanga Agada.

Methodology: Dashanga Agada was prepared as per classics in Gullika (Tablet) form. In-house preparation has been standardized on the basis of organoleptic characters, physical characteristics, Physico-chemical properties, High performance thin layer chromatography (HPTLC) and Thin layer chromatography (TLC) methods.

Results: $p H$ of Dashanga Agada at $5 \%$ aqueous solution was $4.58 \% \mathrm{w} / \mathrm{v}$, Loss on drying at $110^{\circ} \mathrm{C} 10.57 \% \mathrm{w} / \mathrm{w}$, Total Ash 8\% w/w, Acid Insoluble Ash 2.45\% w/w, Water Soluble Ash 23.85\% w/w, Alcohol Soluble Extractive $15.87 \% \mathrm{w} / \mathrm{w}$, Methanol Soluble Extractive $23.66 \% \mathrm{w} / \mathrm{w}$. Fluorescence analysis results indicated no fluorescent material in formulation. Microbial limit test (MLT) showed there was no growth of organisms after 24hrs of incubation as per IP. Thin Layer chromatographic analysis (TLC) showed 10 and 11 picks at 254nm and 366nm respectively.
\end{abstract}

Conclusion: The set parameters can be used as reference standards for the quality control.

KEYWORDS: Dashanga Agada, High performance thin layer chromatography, Standardization.

\section{INTRODUCTION}

Dashanga Agada (DA) an Ayurvedic formulation consists of 9 herbs and 1 mineral in Gullika (Table1) form. It is one of the most widely used Ayurvedic formulation indicated in Kita Visha (Insect bite) ${ }^{[1]}$ by Ayurvedic classics as well as Traditional Kerala Visha Vaidya's.

Table 1: Ingredients of DA

WHO collaborates and assists health ministries in establishing mechanism for the introduction of traditional

\begin{tabular}{|r|l|l|l|l|}
\hline \multicolumn{1}{|l|}{ Sr No } & Drug Name & Latin Name & Part Used & Quantity \\
\hline 1. & Vacha & Acorus calamus Linn. & Kanda (Rhizome) & 1 part \\
\hline 2. & Hingu & Ferula narthex Boiss. & Niryasa (Gummy resin) & 1 part \\
\hline 3. & Vidanga & Embelia ribes Burm. & Phala (Fruit) & 1 part \\
\hline 4. & Saindhava & Rock salt & Phala (Fruit) & Mart \\
\hline 5. & Gajapippali & Scindapsus officinalis Schott. & Kanda (Rhizome) & 1 part \\
\hline 6. & Patha & Cissampelos pareira Linn. & Kanda (Rhizome) \\
\hline 7. & Prativisha & Aconitum heterophylum Wall. & Phala (Fruit ) & 1 part \\
\hline 8. & Shunthi & Zingiber officinale Rosc. & Phala (Fruit ) & 1 part \\
\hline 9. & Maricha & Piper nigrum Linn. & Piper longum Linn. & \\
\hline 10 & Pippali & &
\end{tabular}


WHO collaborates and assist health ministries in establishing mechanism for the introduction of traditional plant medicines into primary healthcare programs, in assessing safety and efficacy, in the quality control of raw and processed materials. ${ }^{[2]}$ The need of quality control for Ayurvedic drugs is due to the fact that the preparation of drug according to the ancient method has been reduced due to the commercialization of Ayurvedic pharmacy in present era. ${ }^{[3]}$ The present study carried out to develop standardization of Dashanga Agada.

\section{MATERIALS AND METHODS}

\subsection{Collection and Identification of plant materials}

The raw drugs used for preparation of DA were procured from KLEU's GMP certified Ayurved Pharmacy, Belgaum, Karnataka, India and authenticated by AYUSH approved Drug Testing Laboratory, KLEU's Shri. BMK Ayurved Mahavidyalaya and Research Centre, Belgaum, Karnataka.

\subsection{Preparation of Dashanga Agada}

All the authenticated drugs were powdered separately, passed through 80 \# sieve and then mixed together in specified proportions (Table 1) to get uniformly blended Churna. The rolled Gullika (Tablets) were prepared after getting desired consistency, shade dried and was packed in a tightly closed glass containers for further use.

\subsection{Chemicals}

Solvents and chemicals of analytical grade were procured from E. Merck and S.D. fine chemicals, Mumbai. Test Solution: Methanol extract of DA.

Stationary Phase: Silica gel $\mathrm{GF}_{254}$ for TLC plates with aluminium sheet support $(0.2 \mathrm{~mm}$ thickness) (E. Merck) were used. Mobile Phase- Toulene:Ethyl acetate $(7: 3 \mathrm{v} / \mathrm{v})$ was selected as solvent system through trial and error method. The developed plates were visualised under visible day light, short UV (254nm), long UV (366nm) and RF values were recorded.

HPTLC - Instrumentation and Chromatographic conditions - The samples were spotted (10 $\mu \mathrm{L})$ in the form of bands of width of $6 \mathrm{~mm}$, with a $100 \mu \mathrm{L}$ sample syringe (Hamilton, Bonaduz, Switzerland) on precoated silica gel aluminium plate $60 \mathrm{~F}_{254}(5 \mathrm{~cm} \mathrm{X10} \mathrm{cm}$ ) with $250 \mu \mathrm{m}$ thickness (E. MERCK, Darmstadt, Germany) using a CAMAG Linomat 5 sample applicator (Switzerland). The slit dimensions $5 \mathrm{~mm} \mathrm{X} 0.45 \mathrm{~mm}$ and scanning speed of $20 \mathrm{~mm} / \mathrm{sec}$ was employed. The linear ascending development was carried out in $10 \mathrm{~cm}$ X 10 $\mathrm{cm}$ twin trough glass chamber (CAMAG, Muttenz, Switzerland) using Toluene: Ethyl Acetate (7:3 v/v) as mobile phase. The optimized chamber saturation time for mobile phase was $15 \mathrm{~min}$. The length of chromatogram run was $9 \mathrm{~cm}$ and development time was approximately $20 \mathrm{~min}$. TLC plates were dried in a current of air with the help of a hair drier. Densitometric scanning was performed on CAMAG thin layer chromatography scanner at $340 \mathrm{~nm}$ for all developments operated by WINCATS software version 1.4.2.

\subsection{Physico chemical evaluation}

DA was subjected to various analytical parameters as follows -

Organoleptic parameters: Rupa (colour), Rasa (Taste), Gandha (odour), Sparsha (Touch), ${ }^{[4]}$ Physico-chemical Parameters: $\mathrm{pH} \% \mathrm{w} / \mathrm{v}$ of aqueous solution. ${ }^{[5]}$ Loss on drying at $110^{\circ} \mathrm{C}^{[6]}$ Ash value. ${ }^{[7]}$ Acid insoluble ash. ${ }^{[8]}$ Water soluble extractive. ${ }^{[9]}$ Hydro alcoholic soluble extractive, methanol soluble extractive. ${ }^{[10]}$

Quantitative test for Gullika: Weight variation test. ${ }^{[11]}$ Tablet hardness test. ${ }^{[12]}$ Tablet disintegration time. ${ }^{[13]}$ Friability. ${ }^{[14]}$

Qualitative test for various functional groups. ${ }^{[15-16]}$

Microbial limit Test was carried out for Fungal and Bacterial study. ${ }^{[17]}$

Fluorescence analysis: The powdered sample of DA was exposed to UV light at wavelength of $254 \mathrm{~nm}$ and 366nm. Results were recorded. ${ }^{[18]}$

Physical Characteristics: Bulk densities, Tap density, Haussner Ratio, Carr's index were determined and recorded. ${ }^{[19-20]}$

\section{RESULTS AND DISCUSSION}

Organoleptic characters for finished product of DA shows - Surface of DA was uniform and without any cracks, was grey in colour, DA was pungent, bitter in Rasa due to more Bhavana, DA having characteristic Gandha (odour) due to the specific ingredients as well as Bhavana Dravya, DA was harder in Sparsha because of reduction in particle size due to more Mardana (Trituration). [Table2] 
Table 2: Organoleptic characters of DA

\begin{tabular}{|l|l|l|}
\hline Sr. No. & Parameters & DA \\
\hline 1 & Colour & Grey \\
\hline 2 & Odour & Characteristic \\
\hline 3 & Taste & Pungent, Bitter \\
\hline 4 & Consistency & Hard \\
\hline
\end{tabular}

Physico chemical analysis - $\mathrm{pH}$ value represents alkalinity and acidic nature of formulation, $\mathrm{pH}$ of DA was weak acidic. Acidic nature of DA was due to Bhavana dravya (Triturating media) given for more duration. Loss of drying indicates the moisture content, in DA it was $10.57 \% \mathrm{w} / \mathrm{w}$. Presence of inorganic substances in the formulations indicated by determination of Ash value, which plays important role in standardization, more ash value denotes higher inorganic substances, in present sample Ash value was $8 \% \mathrm{w} / \mathrm{w}$. Various components have different solubility media, present formulation solubility was seen in water and methanol, Water and methanol soluble extractive value of DA was $23.85 \%, 23.66 \%$ respectively which shows that DA having more bioavailability in water media than methanol.[Table 3]

Table 3: Physicochemical properties of DA

\begin{tabular}{|l|l|l|}
\hline Sr. No. & Parameters & DA \\
\hline 1 & $\mathrm{pH}$ at $5 \%$ aqueous solution $(\% \mathrm{w} / \mathrm{v})$ & 4.58 \\
\hline 2 & Loss on Drying at $110^{\circ} \mathrm{C}(\% \mathrm{w} / \mathrm{w})$ & 10.57 \\
\hline 3 & Total Ash $(\% \mathrm{w} / \mathrm{w})$ & 8 \\
\hline 4 & Acid Insoluble Ash $(\% \mathrm{w} / \mathrm{w})$ & 2.45 \\
\hline 5 & Water Soluble Ash $(\% \mathrm{w} / \mathrm{w})$ & 4.96 \\
\hline 6 & Water Soluble Extractive $(\% \mathrm{w} / \mathrm{w})$ & 23.85 \\
\hline 7 & Alcohol Soluble Extractive $(\% \mathrm{w} / \mathrm{w})$ & 15.87 \\
\hline 8 & Methanol Soluble Extractive $(\% \mathrm{w} / \mathrm{w})$ & 23.66 \\
\hline
\end{tabular}

Average Weight, Disintegration time, Hardness and Friability of DA were given in [Table 4], the weight variation is $+/-2 \%$, by this proper fixation of therapeutic dose can be achieved. Hardness and Disintegration of DA is more due to more Mardana duration, friability was $0.764 \%$, helps to carry easily with less percentage of breakage.

Table 4: Quantitative parameters of DA

\begin{tabular}{|l|l|l|}
\hline Sr. No. & Parameters & DA \\
\hline 1 & Wt. Variation Test & $+/-2 \%$ \\
\hline 2 & Tab. Disintegration Time $(\mathrm{min})$ & 28 \\
\hline 3 & Hardness $\left(\mathrm{Kg} / \mathrm{cm}^{2}\right)$ & 11 \\
\hline 4 & Friability $(\%)$ & 0.764 \\
\hline
\end{tabular}

Qualitative analysis shows presence of Carbohydrates, reducing sugar, alkaloids, proteins, amino acids, fats and oils, steroids, Flavonoids, Saponins was present given in Table 5 and 6 respectively.

Table 5: Qualitative parameters of DA - Organic test

\begin{tabular}{|l|l|l|l|l|l|}
\hline Sr. & Parameters & Test & \multicolumn{2}{|l|}{ DA } \\
\cline { 3 - 6 } No. & & & Aq & A/L & M \\
\hline 1 & Carbohydrates & Molish & + & + & - \\
\hline 2 & Reducing Sugar & Benedict's & + & + & + \\
\hline 3 & Non reducing sugar & Benedict's & - & - & - \\
\hline 4 & Proteins & Biurets test & + & - & - \\
\hline 5 & Amino Acids & -- & + & + & - \\
\hline 6 & Fats and Oils & --- & + & + & - \\
\hline 7 & Volatile oils & --- & - & - & + \\
\hline 8 & Steroids & --- & + & + & - \\
\hline 9 & Glycosides & Cardiac Glycosides & - & - & + \\
\hline 10 & Saponins & --- & + & + & - \\
\hline 11 & Flavonoids & --- & + & - & - \\
\hline 12 & Alkaloids & Dragandroff's & + & + & + \\
\hline
\end{tabular}

+ Present, - Absent, Aq - Aqueous, A/L - Alcoholic, M - Methanolic 
Table 6: Qualitative parameters of DA - Inorganic test

\begin{tabular}{|l|l|l|}
\hline Sr. No. & Parameters & DA \\
\hline 1 & Carbonate & + \\
\hline 2 & Calcium & - \\
\hline 3 & Magnesium & - \\
\hline 4 & Potassium & - \\
\hline 5 & Iron & + \\
\hline 6 & Sulphate & - \\
\hline 7 & Chloride & + \\
\hline 8 & Nitrate & + \\
\hline 9 & Sodium & + \\
\hline
\end{tabular}

+ Present, - Absent

Findings of Physical characteristics, Fluorescence analysis, Microbial limit test (MLT) is given in Table 7-9 respectively. Tapped density gives information on consolidation of powder. The Hausner ratio and Carr's index are both measures of the flow properties. Fluorescence analysis results indicated no fluorescent material in formulation. MLT showed there was no growth of organisms after $24 \mathrm{hrs}$ of incubation as per IP.

Table 7: Physical characteristics of DA

\begin{tabular}{|l|l|l|l|l|l|l|}
\hline Sr. No. & Formulation & $\begin{array}{l}\text { Bulk Density } \\
(\mathbf{g m} / \mathbf{m l})\end{array}$ & $\begin{array}{l}\text { Tap Density } \\
(\mathbf{g m} / \mathbf{m l})\end{array}$ & $\begin{array}{l}\text { Angle of } \\
\text { Repose }\end{array}$ & $\begin{array}{l}\text { Hausner } \\
\text { Ratio }\end{array}$ & $\begin{array}{l}\text { Car's Index } \\
(\mathbf{\%})\end{array}$ \\
\hline 1 & DA & 0.714 & 0.869 & 40.596 & 1.217 & 21.70 \\
\hline
\end{tabular}

Table 8: Fluorescence analysis of DA

\begin{tabular}{|l|l|l|l|l|}
\hline \multirow{2}{*}{ Sr. No. } & \multirow{2}{*}{ Materials } & \multicolumn{2}{l|}{ DA } \\
\cline { 3 - 5 } & & DL & UV 254nm & UV 366nm \\
\hline 1 & Powder As such & LG & DGR & LG \\
\hline 2 & $\mathrm{P}+$ N. NaOH & BR & DBR & GR \\
\hline 3 & $\mathrm{P}+$ Picric Acid & BR & DBR & DGR \\
\hline 4 & $\mathrm{P}+$ Acetic Acid & BR & DBR & DGR \\
\hline 5 & $\mathrm{P}+1 \mathrm{~N} . \mathrm{HCL}$ & $\mathrm{BR}$ & $\mathrm{BL}$ & DGR \\
\hline 6 & $\mathrm{P}+1 \mathrm{~N} . \mathrm{HNO}_{3}$ & $\mathrm{BR}$ & $\mathrm{BL}$ & DGR \\
\hline 7 & $\mathrm{P}+$ Iodine $5 \%$ & $\mathrm{DBR}$ & $\mathrm{DBL}$ & DBR \\
\hline 8 & $\mathrm{P}+5 \% \mathrm{FeCL}_{3}$ & $\mathrm{BR}$ & $\mathrm{DBL}$ & GR \\
\hline 9 & $\mathrm{P}+50 \% \mathrm{HNO}_{3}$ & $\mathrm{BR}$ & $\mathrm{DBL}$ & DGR \\
\hline 10 & $\mathrm{P}+\mathrm{Methanol}$ & $\mathrm{BR}$ & $\mathrm{BL}$ & GR \\
\hline 11 & $\mathrm{P}+$ Methanol + & $\mathrm{DBR}$ & $\mathrm{DBL}$ & DGR \\
& $\mathrm{NaOH}$ & & & \\
\hline
\end{tabular}

LG: light green, BR: brown, DBR: dark brown, DGR: dark green, BL: black, DBL: dark black, GR: green

Table 9: Microbial limit test of DA

\begin{tabular}{|l|l|l|l|}
\hline Sr. No. & Pathogens & Limits (As per IP) & Results \\
\cline { 4 - 4 } & & & DA \\
\hline 1 & E coli & Absent & Absent \\
\hline 2 & S aureus & Absent & Absent \\
\hline 3 & P aeruginose & Absent & Absent \\
\hline 4 & S abony & Absent & Absent \\
\hline
\end{tabular}

TLC analysis - Rf values and TLC plate photograph is shown in Table10 and Fig. 1, 2 respectively.

Table 10: TLC - Rf values of DA

\begin{tabular}{|l|l|l|l|}
\hline Extract & Solvent System & Spots at UV $254 \mathbf{~ n m}$ & Spots at UV 366 nm \\
\hline Methanol & Toulene:Ethyl & $0.09,0.32,0.36,0.42,0.48,0.56$, & $0.10,0.21,0.33,0.46,0.53,0.58$, \\
& Acetate (7:3) & $0.74,0.79,0.31,0.87$ & $0.64,0.72,0.82,0.89,0.93$ \\
\hline
\end{tabular}




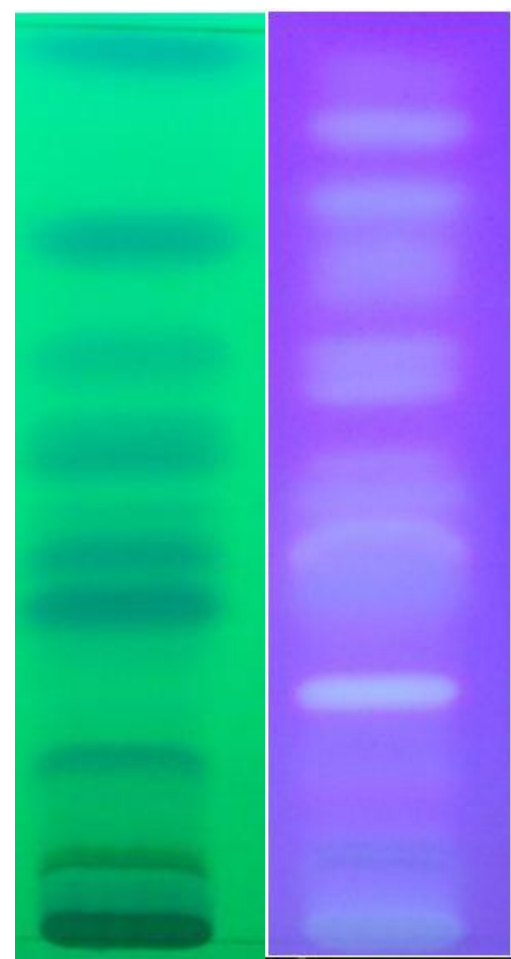

Fig. 1 and 2 - TLC of Methanolic Ext. Of DA at - 254nm 366nm HPTLC profile results shown in Table11 and Fig. 3 respectively.

Table 11: HPTLC analysis of Methanolic Extract at 340nm

\begin{tabular}{|l|l|l|l|}
\hline Peak & Rf & Height & Area \\
\hline 1 & 0.07 & $7.9 \mathrm{AU}$ & $4298.3 \mathrm{AU}$ \\
\hline 2 & 0.50 & $2.0 \mathrm{AU}$ & $378.5 \mathrm{AU}$ \\
\hline 3 & 0.57 & $43.9 \mathrm{AU}$ & $3363.2 \mathrm{AU}$ \\
\hline 4 & 0.70 & $4.1 \mathrm{AU}$ & $6805.1 \mathrm{AU}$ \\
\hline 5 & 0.96 & $0.0 \mathrm{AU}$ & $1426.4 \mathrm{AU}$ \\
\hline
\end{tabular}

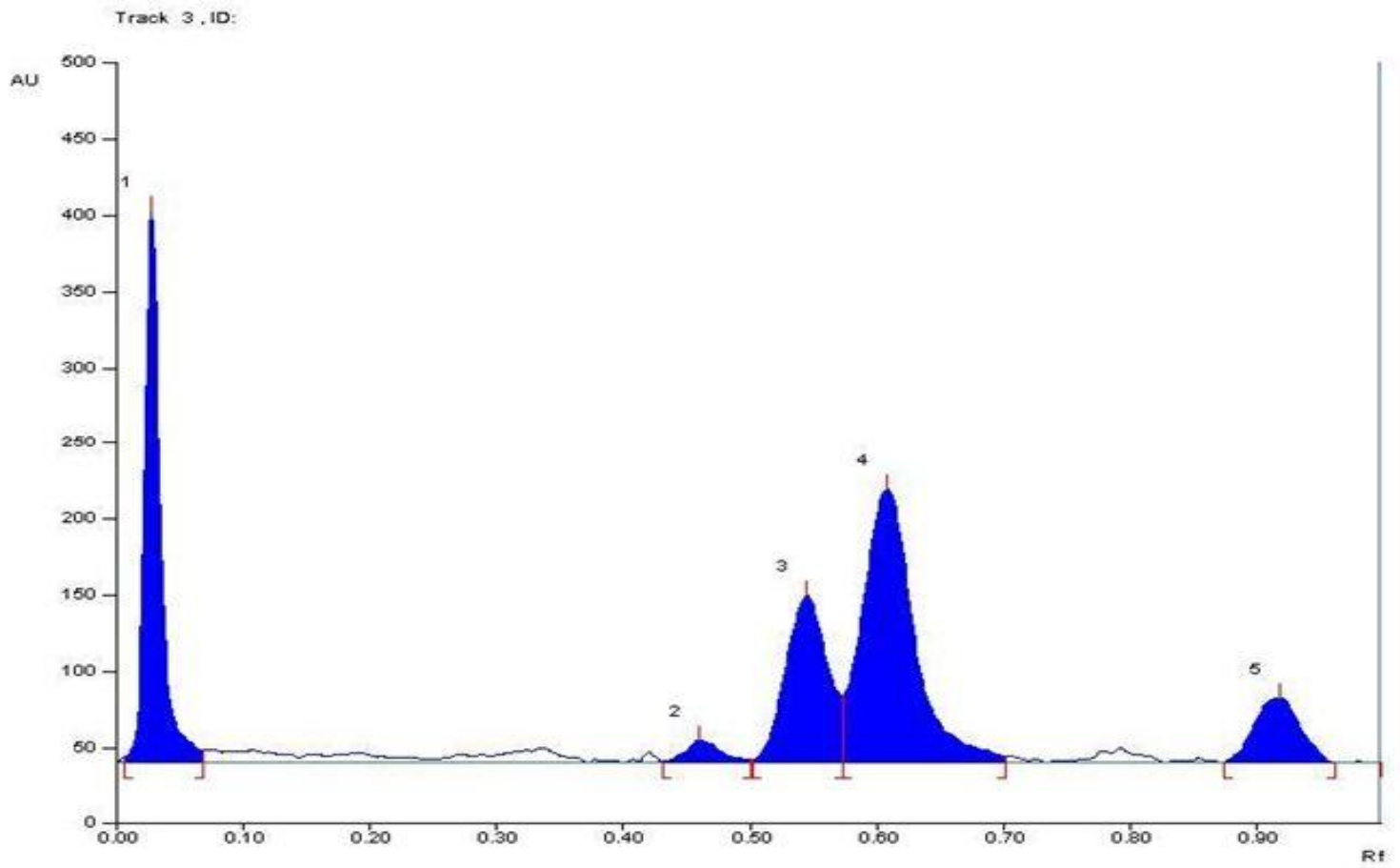

Fig. 3: HPTLC fingerprinting of Methanolic Ext. Of DA 


\section{CONCLUSION}

Present work carried out for development of quality standards of Dashanga Agada. Physicochemical, preliminary phytochemical studies, HPTLC and TLC profile have been useful for identity of Ayurvedic formulation. The results obtained from this study could be utilised for the standardization of formulations.

\section{ACKNOWLEDGEMENT}

The authors would like to acknowledge Dr. B.S. Prasad, Principal, KLEU's Shri BMK Ayurved Mahavidyalaya and research centre, Shahapur, Belgaum for support and providing facilities in Drug Testing Laboratory to carry out research work.

\section{REFERENCES}

[1]. Vagbhata, Ed. By Paradkar HS. Astanga Hrudaya, with Sarwangasundar Tika of Arunadatta and Ayurved Rasayani of Hemadri., Varanasi: Chaukhambha Surabharati Prakashana;2010. p. 916 (Uttar Tantra37/27-28)

[2]. $\quad$ Ekka Neeli Rose, Nmedo KP, Samal PK. Standardization strategies for herbal drugs. Research J. Pharm. and Tech. 2008;19:1115.

[3]. Anonymous. The Ayurvedic Formulary of India, New Delhi; Govt. of India, Ministry of Health and Family Welfare; 1976.

[4]. Siddiqui A, Hakim MA. Format for the pharmacopoeial analytical standards of compound formulation, workshop on standardization of unani drugs, Appendix, New Delhi: Central council for research in unani medicine; 1995. P. 25

[5]. Indian Pharmacopoeia. Government of India, Ministry of Health and Family Welfare. Appendix - 8.1:A-95. New Delhi: Controller of Publication; 1996. P. 2.

[6]. Indian Pharmacopoeia. Government of India, Ministry of Health and Family Welfare. Appendix - 8.7:A-89. New Delhi: Controller of Publication; 1996. P. 2.

[7]. Indian Pharmacopoeia. Government of India, Ministry of Health and Family Welfare. Appendix - 8.38:A-54. New Delhi: Controller of Publication; 1996. P. 2.

[8]. Indian Pharmacopoeia. Government of India, Ministry of Health and Family Welfare. Appendix - 8.38:A-54. New Delhi: Controller of Publication; 1996. P. 2.

[9]. Indian Pharmacopoeia. Government of India, Ministry of Health and Family Welfare. Appendix - 8.38:A-54. New Delhi: Controller of Publication; 1996. P. 2.

[10]. Indian Pharmacopoeia. Government of India, Ministry of Health and Family Welfare. New Delhi: Controller of Publication; 1996; 2:735. P. 2.

[11]. Indian Pharmacopoeia. Government of India, Ministry of Health and Family Welfare. New Delhi: Controller of Publication; 1996; $2: 736$. P. 2.

[12]. Indian Pharmacopoeia. Government of India, Ministry of Health and Family Welfare. New Delhi: Controller of Publication; 1996; 2:734. P. 2.

[13]. Indian Pharmacopoeia. Government of India, Ministry of Health and Family Welfare. Appendix - 7.1:A-80. New Delhi: Controller of Publication; 1996. P. 2.

[14]. Indian Pharmacopoeia. Government of India, Ministry of Health and Family Welfare. Appendix - 7.1:A-80. New Delhi: Controller of Publication; 1996. P. 2.

[15]. Khandelwal KR, Practical Pharmacognocy. $12^{\text {th }}$ ed. Pune: Nirali Prakashan;2004. P. 149-60.

[16]. Pharmacopeial standards for Ayurvedic formulations, Central Council for Research for Ayurveda and Siddha, Revised Ed. Ministry of Health and Family Welfare, Government of India; New Delhi 1987. P. 1-20.

[17]. Indian Pharmacopoeia. Government of India, Ministry of Health and Family Welfare. Appendix - 9.3:A-110. New Delhi: Controller of Publication; 1996. P. 2.

[18]. Chase CR, Pratt R. Fluorescence of powdered vegetable drugs with particular reference to development of a system of identification. J Am Pharm Assoc 1949;38:324-31

[19]. Lachman L, Liberman HA, Kanig JL. The theory and practice of industrial Pharmacy, Mumbai: Varghese Publishing House; 1987.

[20]. Aulton ME. Pharmaceutics, The science of dosage forms design. New Delhi: Churchill Livingstone; 2002. P. 205. 